\title{
Astroglial Differentiation of Cortical Precursor Cells Triggered by Activation of the cAMP-Dependent Signaling Pathway
}

\author{
Matthew F. McManus, Li-Chun Chen, Inmaculada Vallejo, and Mario Vallejo \\ Reproductive Endocrine Unit, Massachusetts General Hospital, Harvard Medical School, Boston, Massachusetts 02114
}

In the developing brain, differentiation of neural precursors into neurons or glial cells occurs in response to neurotrophic factors acting on the cell surface. Intracellular signaling mechanisms that relay information to initiate differentiative responses of neural precursor cells are poorly understood. To investigate whether stimulation of the cAMP-dependent signaling pathway participates in differentiative responses of cells in the developing CNS, we performed experiments using both conditionally immortalized neural precursor cells (RC2.E10 cells) and primary cultures of cells from developing rat cortex. Initially, we determined that RC2.E10 cells retain phenotypic features of neural precursors after inactivation of the immortalizing oncogene, a temperature-sensitive mutant of the simian virus 40 large-T antigen (SV40T). We found that, once SV40T is inactivated, RC2.E10 cells cease to divide and die. However, RC2.E10 cells can proliferate in the presence of basic fibroblast growth factor.
In addition, they express nestin, a marker of neural precursor cells. Both RC2.E10 cells and primary cortical precursor cells undergo astroglial differentiation in response to CAMP stimulation by treatment with 8-bromo-cAMP. In both cases, cAMPinduced astrocyte differentiation is characterized by morphological changes, stimulation of glial fibrillary acidic protein expression, downregulation of nestin expression, and decreased proliferation. No increases in the expression of neuronal or oligodendrocytic markers were observed. Our results support the notion that the developing CNS contains neural precursor cells with the capacity of undergoing astrocyte differentiation in response to increased intracellular cAMP concentrations.

Key words: neural precursor cells; astrocyte differentiation; cortical development; cAMP; conditional immortalization; GFAP; nestin
During embryonic development, discrete populations of proliferating progenitor cells in the neural tube respond to signals that determine their commitment to differentiate into neuronal or glial lineages (Johe et al., 1996; McKay, 1997). Choices taken by neural precursors have been investigated with recombinant retroviruses as tracers of cell fates (Halliday and Cepko, 1992; Reid et al., 1995; Williams and Price, 1995) or by analyzing the fate of clonal immortalized precursor cell lines engrafted after transplantation into the developing CNS (Renfranz et al., 1991; Snyder et al., 1992; Vicario-Abejón et al., 1995a; Brüstle et al., 1997). However, these studies do not provide information about the environmental factors to which precursor cells respond or the intracellular signaling mechanisms that are activated to promote differentiation.

In recent years a number of factors that govern the differentiative potential of neural precursors have been identified. Among them, basic fibroblast growth factor (bFGF) is important to maintain proliferation (Ray et al., 1993; Gage et al., 1995; Ghosh and Greenberg, 1995; Vicario-Abejón et al., 1995b; Johe et al., 1996; Cavanagh et al., 1997); ciliary neurotrophic factor (CNTF) and bone morphogenetic proteins promote the differentiation of as-

\footnotetext{
Received March 26, 1999; revised Aug. 5, 1999; accepted Aug. 6, 1999.

This work was supported in part by US Public Health Service Grant DK-49670 and by a grant from the Whitehall Foundation. I.V. was partially supported by a fellowship from the University of Cadiz (Spain). We thank Joel Habener for access to image analysis system to quantify nuclear BrdU incorporation, Guillermina Almazán for retrovirus-producing $\psi-2$ fibroblasts, David Ron for pGEM7ZAd, Sanjun Zhen for preliminary contributions, and Beatriz Perez-Villamil and Petra Schwartz for critical reading of the manuscript. M.M. is presently in the Case Western Reserve University (Cleveland, OH) Medical Scientist Training Program.

Correspondence should be addressed to Dr. Mario Vallejo, Instituto de Investigaciones Biomedicas, Calle Arturo Duperier 4, 28029 Madrid, Spain.

Copyright (C) 1999 Society for Neuroscience $\quad 0270-6474 / 99 / 199004-12 \$ 05.00 / 0$
}

trocytes (Rao et al., 1988; Gross et al., 1996; Bonni et al., 1997); platelet-derived growth factor, neurotrophin-3, and brain-derived neurotrophic factor induce neuronal differentiation (Ghosh and Greenberg, 1995; Vicario-Abejón et al., 1995b; Johe et al., 1996); and finally, hormonal activation of certain nuclear receptors leads to generation of oligodendrocytes (Barres et al., 1994; Johe et al., 1996).

Phenotypic transitions induced in neural precursor cells by neurotrophic molecules are the consequence of coordinated changes in the expression of specific sets of genes. Therefore, stimulation of intracellular signaling pathways that results in the rapid activation of transcription factors that relay information to the nucleus is a likely mechanism by which extracellular factors induce differentiation (Segal and Greenberg, 1996; Bonni et al., 1997; Rajan and McKay, 1998). Stimulation of the cAMPdependent signaling pathway represents one possible mechanism for the activation of transcriptional programs that result in phenotypic changes during development.

Stimulation of cAMP signaling leads to the activation of protein kinase A (PKA), which phosphorylates transcription factors such as cAMP response element-binding protein (CREB) (Montminy, 1997). CREB, which can be phosphorylated also by other kinases activated by different neurotrophic factors (Ghosh and Greenberg, 1995; Xing et al., 1996; Finkbeiner et al., 1997; Pende et al., 1997), has been associated with changes in cellular plasticity in the adult and developing CNS (Liu and Graybiel, 1996; Moore et al., 1996; Murphy and Segal, 1997). In addition, cAMP regulates the activity of guanine nucleotide exchange factors that trigger signaling mechanisms independent of PKA (Kawasaki et al., 1998). However, it is not known whether activation of cAMP signaling participates in the differentiative responses of neural 
precursor cells. In the present study, we report on the initiation of astrocytic differentiation of cultured cortical precursors after stimulation of the cAMP-dependent signaling pathway.

\section{MATERIALS AND METHODS}

Materials. DNA-modifying enzymes were purchased from New England Biolabs (Beverly, MA), or Promega (Madison, WI). Radioactive compounds were obtained from DuPont New England Nuclear (Boston, MA). Nucleotides were purchased from Pharmacia (Piscataway, NJ). Tissue culture medium was prepared by the Cell Culture Core Facility of the Reproductive Endocrine Sciences Center at Massachusetts General Hospital, and reagents were obtained from Life Technologies (Grand Island, NY). All other reagents were obtained from Sigma (St. Louis, MO) unless otherwise specified.

Plasmids. Construction of expression plasmids encoding the $\mathrm{C}$-terminal region of nestin was performed with a fragment of nestin cDNA generated by RT-PCR as follows. Total RNA $(10 \mu \mathrm{g})$ purified by $\mathrm{CsCl}$ gradient centrifugation from whole brains dissected from embryonic day 15 (E15) rats was primed with poly(dT) $)_{15}$ and incubated with avian myeloblastosis virus reverse transcriptase (Boehringer Mannheim, Indianapolis, IN) to synthesize cDNA. This was used as a template to amplify a fragment of cDNA encoding 207 amino acids of the $\mathrm{C}$-terminal region of nestin (C/Nestin, residues $1599-1805)$ by PCR, using specific primers designed from the published sequence of the nestin cDNA (Lendahl et al., 1990). The sequence of the forward primer is $5^{\prime}$ ACGGATCCGATGGGTTTGCTGATGAG-3', and that of the reverse primer is $5^{\prime}$-CAGAATTCAGCCAGAGGGGCAGTTTC- $3^{\prime}$. These primers incorporate Bam $\mathrm{HI}$ and EcoRI sites at their ends, respectively. PCR conditions were $95^{\circ} \mathrm{C}$ for $5 \mathrm{~min}$, followed by 30 cycles of $94^{\circ} \mathrm{C}$ for 30 sec, $50^{\circ} \mathrm{C}$ for $30 \mathrm{sec}$, and $72^{\circ} \mathrm{C}$ for $1 \mathrm{~min}$, after which a 5 min incubation at $72^{\circ} \mathrm{C}$ followed. The PCR product was digested with BamHI and Eco RI and cloned into the plasmid pGEX-KG (Guan and Dixon, 1991) for bacterial expression of a fusion protein composed of glutathione $S$-transferase (GST) and the C terminus of nestin.

For the construction of a eukaryotic expression plasmid encoding the C-terminal 207 amino acid fragment of nestin (C/Nestin), a similar PCR was performed, with the exception that the forward primer was replaced by another with the following sequence: $5^{\prime}$-GCCACCATGGATGGGTTTGCTGATGAG-3'. The resulting fragment, which encodes nestin residues 1599-1805 and incorporates an in-frame initiation methionine encoded within an $\mathrm{NcoI}$ restriction site at the $5^{\prime}$ end, was digested with $\mathrm{NcoI}$ and EcoRI, and ligated into the shuttle vector pGEM7ZAd (a gift of David Ron, New York University, New York, NY). pGEM7ZAd contains inserted into its HindIII-EcoRI sites a unique NcoI site that places the initiating methionine-encoding codon in the context of an optimal ribosomal binding Kozak sequence (Ron and Habener, 1992). The resulting pGEM7ZAd-C/Nestin was subsequently digested with HindIII and EcoRI, and the insert was cloned into similarly digested pcDNAI (Invitrogen, Carlsbad, CA) for the expression of the C-terminal tail of nestin under the control of the cytomegalovirus promoter.

Generation of anti-nestin antiserum. Bacterial expression of GST-C/ Nestin was induced in exponentially growing Escherichia coli JM109 treated with $0.4 \mathrm{~mm}$ isopropyl- $\beta$-thiogalactopyranoside for $3 \mathrm{hr}$. The recombinant fusion protein was then purified using glutathioneSepharose 4B beads (Pharmacia), and it was used subsequently to inoculate two rabbits following standard protocols. Only one of the resulting antisera is reported in these studies. Specificity of anti-nestin antiserum was determined by Western immunoblot (1:20,000 dilution). For immunocytochemistry it was used at 1:10,000 dilution.

Transfections. COS- 1 cells were transfected with the DEAE method as described (Cato et al., 1986), with the exception that plasmid DNA was left in contact with cells for $3 \mathrm{hr}$.

Establishment of RC2.E10 cells. Primary cultures of cells from developing cerebral cortex were prepared from E16 fetuses removed from timed-pregnant Sprague Dawley rats. Fetuses were placed in PBS for the dissection of the brain, which was subsequently transferred to HBSS (Life Technologies). The cerebral cortex was separated on both sides from the rest of the brain using iridectomy scissors, and the meningeal membranes were carefully removed. The resulting pieces were incubated with $0.025 \%$ trypsin and dissociated by trituration into a homogeneous cerebrocortical cell suspension which was pelleted and resuspended in DMEM supplemented with $10 \%$ heat-inactivated fetal bovine serum (FBS). Cells were seeded on plates previously coated with poly-Dornithine (Sigma) at a density of $100,000 \mathrm{cells} / \mathrm{cm}^{2}$ and cultured at $37^{\circ} \mathrm{C}$ in a humidified $5 \% \mathrm{CO}_{2}$ incubator. The following day, cells were infected as described (Renfranz et al., 1991) with a replication-defective recombinant retrovirus derived from the Moloney murine leukemia virus that contains a neomycin resistant gene and a simian virus 40 large- $T$ antigen (SV40T) oncogene encoding the $t s A 58 / U 19$ temperature-sensitive mutant allele (Jat and Sharp, 1989; Almazan and McKay, 1992). Retroviral particles (titer, $10^{5}$ colony-forming units $/ \mathrm{ml}$ ) were produced by a $\Psi-2$ packaging fibroblast cell line (F4 subclone; kindly provided by Dr. G. Almazan, McGill University, Montreal, Quebec, Canada). Conditioned medium from $\Psi-2$ fibroblasts was filtered and applied for $2 \mathrm{hr}$ directly onto primary cultured cells in the presence of $8 \mu \mathrm{g} / \mathrm{ml}$ polybrene (Sigma). Cells were incubated at $33^{\circ} \mathrm{C}$ in DMEM supplemented with $10 \%$ FBS in the presence of the neomycin analog G418 (Life Technologies). Resistant colonies appeared 3-5 weeks later and were individually picked using cloning rings and expanded. After five to six passages, a fraction of cells from each colony was frozen in liquid nitrogen. A total of 38 cell lines were established, one of which, named RC2.E10, has been cultured in our laboratory for $>2$ years undergoing $>60$ passages with no appreciable changes in phenotypic features (Schwartz and Vallejo, 1998).

Growth curves, proliferation, and differentiation of RC2.E10 cells. To determine growth curves, RC2.E10 cells were plated into $60 \mathrm{~mm}$ tissue culture dishes at initial densities of $10^{4}, 3 \times 10^{4}$, or $10^{5}$ cells per dish and maintained at $33^{\circ} \mathrm{C}$ in DMEM and $10 \%$ FBS for the specified number of days. On day 0 , some plates were incubated for $4 \mathrm{hr}$ after plating to allow cells to attach to the surface of the dish, after which they were transferred to a $39^{\circ} \mathrm{C}$ incubator. Cells in this group of plates were either maintained in DMEM and 10\% FBS or washed and cultured in serum-free DMEM. At different time points (every $24 \mathrm{hr}$ ) cells were trypsinized, collected by centrifugation, and counted with a hemocytometer. Culture media of the remaining cells were changed every $2 \mathrm{~d}$.

Proliferation rates of RC2.E10 cells in different culture conditions were determined by assessing bromodeoxyuridine (BrdU) incorporation immunocytochemically using an Amersham (Arlington Heights, IL) RPN 20 cell proliferation kit. Cells growing in $100 \mathrm{~mm}$ dishes were trypsinized and plated in $35 \mathrm{~mm}$ dishes at a density of $2 \times 10^{4}$ cells $/ \mathrm{cm}^{2}$ and incubated at $33^{\circ} \mathrm{C}$ in DMEM and $10 \%$ FBS for at least $24 \mathrm{hr}$. After this time, BrdU $(10 \mu \mathrm{M})$ was added, and cells were further incubated overnight (16-18 hr). Cells were fixed in acid and ethanol (90\% ethanol and 5\% acetic acid) and processed for immunocytochemistry with a monoclonal anti-BrdU antibody. Control cells that had not been treated with BrdU were processed in parallel in an identical manner. Immunodetection was performed with a biotinylated horse anti-mouse antiserum (Bio-Rad, Hercules, CA) using nickel-ammonium-enhanced immunoperoxidase staining. Fields of vision were either photographed using a Zeiss (Thornwood, NY) Axioscope or captured with a Nikon (Tokyo, Japan) microscope equipped with an Optronics TEC-470 charge-coupled device camera (Optronics Engineering, Goleta, CA) interfaced with a PowerMac 7100 computer, and analyzed with IP Lab spectrum analysis software (Signal Analitics Corp., Vienna, VA). BrdU incorporation was quantified by determining the percentage of BrdU-labeled cells relative to the total number of cells per field of vision as observed by phasecontrast microscopy. Experiments were performed in duplicate, and at least $10-12$ fields of vision per dish were quantified.

For experiments involving incubation at the nonpermissive temperature, cells were allowed to recover from trypsinization for $6-8 \mathrm{hr}$ at $33^{\circ} \mathrm{C}$ in DMEM and 10\% FBS. After this, medium was removed from dishes and replaced by serum-free DMEM containing N1 supplement (Sigma) and $1 \mathrm{~mm}$ sodium pyruvate (defined medium) (Bottenstein and Sato, 1979), to which bFGF $(20 \mathrm{ng} / \mathrm{ml})$ was added. At this point, they were transferred to a different incubator and cultured at $39^{\circ} \mathrm{C}$ in a humidified atmosphere containing $5 \% \mathrm{CO}_{2}$. BrdU was added $2 \mathrm{~d}$ after transferring the cells to the high-temperature incubator.

For differentiation experiments, RC2.E10 cells were allowed to recover from trypsinization for $4 \mathrm{hr}$ at $33^{\circ} \mathrm{C}$ in DMEM and $10 \% \mathrm{FBS}$ and were subsequently transferred to defined medium containing bFGF (20 $\mathrm{ng} / \mathrm{ml})$ and incubated at $39^{\circ} \mathrm{C}$ for at least $30 \mathrm{hr}$. Then, 8-bromo-cAMP (8Br-cAMP; $1 \mathrm{mM})$ or forskolin $(10 \mu \mathrm{M})$ was added to the medium, and incubation proceeded overnight at $39^{\circ} \mathrm{C}$, after which cells were fixed and processed for immunocytochemistry.

Primary cortical cell cultures. The cerebral cortex from fetal brains of E17 Sprague Dawley rats were dissected as described above, and cell suspensions were generated by trituration in HBSS without the addition of trypsin. Cells were pelleted, resuspended in defined medium supplemented with bFGF (20 ng/ml), seeded into poly-D-ornithine-coated 10 $\mathrm{cm}$ dishes at a density of $2-4 \times 10^{4}$ cells $/ \mathrm{cm}^{2}$, and maintained at $37^{\circ} \mathrm{C}$. 
Medium was changed every $2 \mathrm{~d}$, and cells were passaged before reaching confluence (usually $5-6 \mathrm{~d}$ after plating) by treatment with $0.025 \%$ trypsin, which was inactivated by adding DMEM and $10 \%$ FBS. Cells were then washed, resuspended in defined medium containing bFGF, and seeded either into $10 \mathrm{~cm}$ dishes for expansion (1:3 ratio) or into $35 \mathrm{~mm}$ dishes for differentiation experiments, in which case plating density was $3 \times 10^{4}$ cells $/ \mathrm{cm}^{2}$. Cells were not trypsinized more than twice before an experiment was performed.

For differentiation experiments, cells were incubated at $37^{\circ} \mathrm{C}$ for at least $24 \mathrm{hr}$ after plating. At this time, bFGF-containing medium was replaced with bFGF-free defined medium, and 8Br-cAMP $(1 \mathrm{~mm})$ or forskolin $(10 \mu \mathrm{M})$ was added. Cells were further incubated for 2 or $5 \mathrm{~d}$, at the end of which they were processed for immunocytochemistry. For proliferation studies, BrdU $(10 \mu \mathrm{M})$ was added to cells either 5 or $16 \mathrm{hr}$ before they were fixed. BrdU incorporation was detected immunocytochemically, and the proportion of labeled cells was determined as described above.

Western immunoblots. E17 rat forebrain or cells growing in $35 \mathrm{~mm}$ dishes were lysed in buffer containing $125 \mathrm{~mm}$ Tris-HCl, pH 6.8, 4\% SDS, $15 \%$ glycerol, $10 \% \beta$-mercaptoethanol, and $10 \mathrm{~mm}$ dithiothreitol. Proteins were resolved by SDS-PAGE and blotted onto a nitrocellulose membrane. Monoclonal primary antibodies were used to detect SV40T (1:1000 dilution, clone PAb 416; Calbiochem, La Jolla, CA), and glial fibrillary acidic protein (GFAP; 1:10,000 dilution, clone G-A-5; Sigma), followed by incubation with a horse anti-mouse peroxidase-conjugated secondary antibody (1:5000 dilution; BioRad, Hercules, CA). CREB immunoreactivity was detected with a rabbit polyclonal primary antiserum (1:500 dilution; Santa Cruz Biotechnology, Santa Cruz, CA), followed by incubation with a goat anti-rabbit peroxidase-conjugated secondary antibody (1:10,000 dilution) (Bio-Rad). Immunoreactive bands were visualized using an enhanced chemiluminescence detection system (Amersham, Buckinghamshire, England).

Immunocytochemistry. Immunocytochemistry was performed with cells plated into poly-D-ornithine-coated $35 \mathrm{~mm}$ tissue culture dishes. Cells were fixed in $4 \%$ paraformaldehyde in PBS for $5 \mathrm{~min}$, washed in PBS, and permeabilized with methanol for $2 \mathrm{~min}$ at $-20^{\circ} \mathrm{C}$. After blocking with normal goat serum (for polyclonal antisera) or normal horse serum (for monoclonal antibodies) for $1 \mathrm{hr}$, cells were incubated overnight with the corresponding primary antisera at $4^{\circ} \mathrm{C}$. Polyclonal antisera used were nestin (1:10,000 dilution), calbindin D-28K (1:1000 dilution) (Moratalla et al., 1996), neural cell adhesion molecule (NCAM; 1:500 dilution; Santa Cruz Biotechnology), and galactocerebroside (1: 1000 dilution; Sigma). Monoclonal antibodies for SV40T (1:100 dilution, clone PAb 416; Calbiochem), MAP-2 (1:300 dilution, clone HM-2; Sigma), S100 $\beta$ (1:500 dilution, clone SH-B1; Sigma) and GFAP (1:300 dilution, clone G-A-5; Sigma) were used. Immunodetection was performed with secondary biotinylated goat anti-rabbit or horse anti-mouse antisera (Bio-Rad) using immunoperoxidase staining with a Vectastain $\mathrm{ABC}$ kit (Vector Laboratories, Burlingame, CA).

Two-color dual antigen immunocytochemistry was performed serially, basically as described (Moratalla et al., 1996). First, BrdU was detected as described above, using immunoperoxidase staining enhanced with nickel-ammonium, which yields a dark purplish gray color. Once developed, cells were washed, and GFAP immunocytochemistry proceeded as described above, using immunoperoxidase staining without nickel-ammonium, which yields a brown color.

RT-PCR and Southern blot hybridization. Total RNA $(10 \mu \mathrm{g})$ purified from RC2.E10 cells using Triazol (Life Technologies) was primed with poly $(\mathrm{dT})_{15}$ and incubated with avian myeloblastosis virus reverse transcriptase (Boehringer Mannheim) to synthesize cDNA. For PCR amplification of nestin, primers and conditions were identical to those used to construct pcDNAI-C/Nestin (see above), except that only 27 PCR cycles were used. After PCR, an aliquot of the reaction was resolved in a $1 \%$ agarose gel, blotted onto a nylon membrane, probed with a ${ }^{32} \mathrm{P}$-labeled internal primer (5'-ATTCCTGGTCCTCAGGGGAAGAC-3') that corresponds to nucleotides 5520-5542 of the nestin cDNA (Lendahl et al., 1990), and autoradiographed at $-70^{\circ} \mathrm{C}$. For PCR amplification of actin, the primers used were as follows: forward, 5'-GACGATATGGAGAAGATTTGGCA-3', which anneals to exon 2; reverse, 5'-CCATCTCTTGCTCGAAGTCTAGG-3', which anneals to exon 3. The following protocol was used: $94^{\circ} \mathrm{C}$ for $5 \mathrm{~min}$, followed by 20 cycles of $94^{\circ} \mathrm{C}$ for $30 \mathrm{sec}, 55^{\circ} \mathrm{C}$ for $30 \mathrm{sec}$, and $72^{\circ} \mathrm{C}$ for $30 \mathrm{sec}$, after which a $5 \mathrm{~min}$ incubation at $72^{\circ} \mathrm{C}$ followed. As a probe to detect the PCR product after blotting onto nitrocellulose, the following ${ }^{32} \mathrm{P}$-labeled internal primer was used: 5'-CACACGCAGCTCATTGTAGAAAGT-3'.

\section{RESULTS}

Initially, we used embryonic cortex-derived RC2.E10 cells, a clonally expanded cell line immortalized by expression of a temperature-sensitive mutant allele of SV40T (Schwartz and Vallejo, 1998). RC2.E10 cells were routinely propagated at $33^{\circ} \mathrm{C}$ in the presence of FBS. Under these conditions, they exhibit a flat, elongated morphology with relatively large nuclei surrounded by abundant cytoplasm, with the occasional cell extending short processes. After reaching confluence, cells become polygonal and form a compact epithelial monolayer covering the entire surface of the culture plate, and at this point cell growth is inhibited.

\section{Temperature-dependent inactivation of SV40T in RC2.E10 cells}

It is likely that the presence of the immortalizing SV40T prevents cells from exiting the cell cycle and inhibits differentiation (Fanning, 1992). Because one purpose of our study was to investigate the differentiation potential of RC2.E10 cells, we proceeded to the inactivation of this oncogene by raising the incubation temperature to $39^{\circ} \mathrm{C}$. Cells growing at $33^{\circ} \mathrm{C}$ were found to exhibit nuclei with abundant SV40T immunoreactivity, as assessed by immunocytochemistry, using a monoclonal anti-SV40T antibody (Fig. 1A). When the temperature of incubation was shifted to the nonpermissive $39^{\circ} \mathrm{C}$, SV40T immunoreactivity was significantly reduced after $8 \mathrm{hr}$ and was undetectable after a $24 \mathrm{hr}$ incubation (Fig. $1 B$ ). In a different set of experiments, Western immunoblotting using the same antibody revealed that degradation of the SV40T protein proceeded gradually and was maximum by $24 \mathrm{hr}$ (Fig. 1C).

\section{Growth curve and proliferation of RC2.E10 cells in different culture conditions}

The growth curve of RC2.E10 cells cultured at 33 or $39^{\circ} \mathrm{C}$ in the presence or absence of serum was determined by counting cells at different time intervals after plating. Cells maintained at $33^{\circ} \mathrm{C}$ in DMEM and 10\% FBS showed continuous growth with an approximate doubling time of $36 \mathrm{hr}$ (Fig. $2 A$ ). When the temperature of incubation was raised to $39^{\circ} \mathrm{C} 4 \mathrm{hr}$ after plating and maintained for several days, the number of cells increased for 2-3 $\mathrm{d}$, but after this time no further increase was observed, and a clear decline occurred after 4-5 d (Fig. 2B). Finally, when cells were cultured at $39^{\circ} \mathrm{C}$ in serum-free medium the cell number decreased gradually, and practically all of them had died 5-6 d after plating (Fig. 2B). Similar results were obtained in experiments performed with different plating densities, ranging between $10^{4}$ and $10^{5}$ cells per dish.

RC2.E10 cell proliferation was also evaluated by determining the relative number of cells that incorporate BrdU. After an overnight incubation with BrdU, a relatively large number of cells $(60-70 \%)$ were found to incorporate $\mathrm{BrdU}$ when cultured at $33^{\circ} \mathrm{C}$ in the presence of $10 \%$ FBS (Fig. 2). Increasing the temperature of incubation to $39^{\circ} \mathrm{C}$ markedly reduced the number of cells that incorporated $\mathrm{BrdU}$, although a significant number of proliferating cells remained (Fig. 2). When cells were incubated at $39^{\circ} \mathrm{C}$ in defined medium lacking FBS, a significant reduction in the number of proliferating cells was observed compared with those grown under the same conditions but in serum-containing medium (Fig. 2). Thus, these data indicate that serum provides mitogenic factors capable of stimulating proliferation of RC2.E10 cells. However, it appears that the presence of SV40T is required for long-term survival, and therefore RC2.E10 cells are conditionally immortalized cells. Similar results were obtained in ex- 

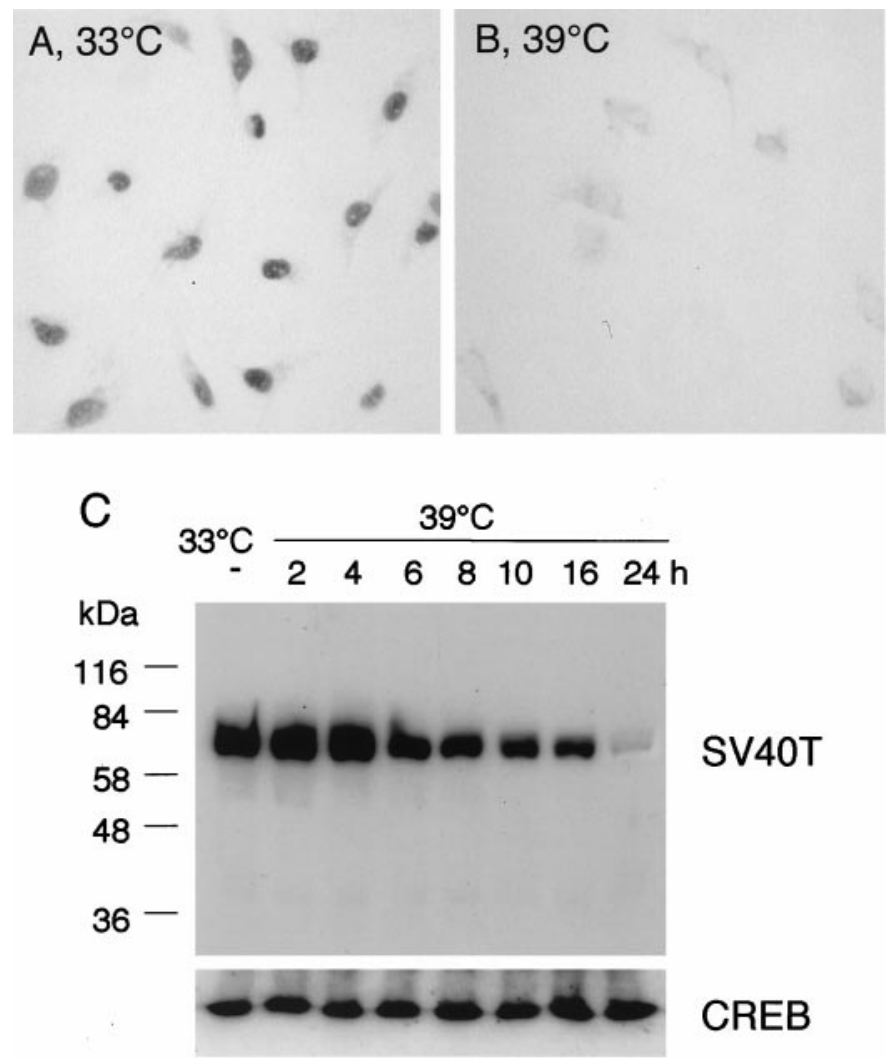

Figure 1. Temperature-dependent expression of the tsA58/U19 SV40 T-antigen. $A, B$, Immunocytochemistry of RC2.E10 cells grown in DMEM and $10 \%$ FBS either at $33^{\circ} \mathrm{C}(A)$ or at $39^{\circ} \mathrm{C}(B)$ for $24 \mathrm{hr}$ performed in parallel with an anti-SV40T monoclonal antibody $(1: 100$ dilution). $A, \mathrm{SV} 40 \mathrm{~T}$-immunopositive cell nuclei, detected after culturing cells at the permissive temperature. $B$, In contrast, SV40T immunoreactivity is not detected in cells cultured at the nonpermissive temperature, indicating temperature-dependent degradation of the oncogene. $C$, Western immunoblot showing time course of the temperature-dependent degradation of the SV40T mutant. All cells were grown in DMEM and 10\% FBS and harvested at the indicated times after increasing the temperature of incubation to $39^{\circ} \mathrm{C}$. Note that a shift from the permissive to the nonpermissive temperature did not affect immunoreactive levels of CREB, used as a control. Approximately $5 \mu \mathrm{g}$ of protein were loaded in each lane.

periments in which the time of exposure to BrdU was reduced to $2 \mathrm{hr}$, although the relative percentage of cells labeled was lower and no labeled cells were observed when incubation was performed at $39^{\circ} \mathrm{C}$ in the absence of FBS (results not shown).

We investigated whether bFGF is sufficient to stimulate proliferation of RC2.E10 cells in serum-free medium, because this growth factor has been shown to provide a mitogenic stimulus to maintain proliferation of cortical neural precursor cells (Ghosh and Greenberg, 1995). We found that addition of bFGF (20 $\mathrm{ng} / \mathrm{ml}$ ) to $\mathrm{RC} 2 . \mathrm{E} 10$ cells maintained at $39^{\circ} \mathrm{C}$ in defined medium significantly increased the number of BrdU-labeled cells to levels that were not significantly different from those observed in the presence of FBS (Fig. 2).

\section{RC2.E10 cells are neuroepithelial precursors}

To further investigate whether RC2.E10 cells exhibit phenotypic features of neural precursors, we sought to determine whether they express nestin, a marker of undifferentiated neural precursor cells (Lendahl et al., 1990). A rabbit anti-nestin antiserum was raised against the $\mathrm{C}$-terminal region of the protein, and its spec- ificity was initially tested by Western immunoblot using bacterially expressed GST-C/Nestin that had been cleaved with thrombin (Guan and Dixon, 1991). The antiserum was shown to recognize both the GST and the truncated nestin fragments (Fig. $3 A$ ). The $\mathrm{C}$-terminal region of nestin was also expressed in COS cells transfected with pcDNAI-C/Nestin and assayed by Western immunoblot. No signal was detected in control cells transfected with pcDNAI containing no insert, but a single band of the expected molecular mass was detected in cells transfected with pcDNAI-C/Nestin (Fig. 3B). Preincubation of the antiserum with purified GST did not disturb this band, but it was abolished by preincubation with purified GST-C/Nestin (Fig. 3B). Finally, to test whether the antiserum could recognize endogenous nestin, Western immunoblots were performed using lysates of embryonic brain dissected from E17 rat fetuses, and a single band with an apparent molecular mass of $\sim 200 \mathrm{kDa}$ was observed (Fig. $3 C$ ). A similar result was obtained using E15 rat fetuses (result not shown). This band was not altered when the antiserum was preincubated with purified GST but was not detectable when the antiserum was preincubated with GST-C/Nestin (Fig. 3C).

To determine whether RC2.E10 cells express nestin, both Western immunoblot and immunocytochemistry were performed. By Western immunoblot, lysates of cells growing at $39^{\circ} \mathrm{C}$ in the presence of bFGF $(20 \mathrm{ng} / \mathrm{ml})$ generated a single immunoreactive band of relatively high molecular mass that comigrated with the one observed in embryonic brain lysates (Fig. 3C). By immunocytochemistry, cells were found to have immunoreactive cytoplasm (Fig. 3D). This immunoreactivity was not altered when the antiserum was preincubated with purified GST but was undetectable when antiserum preincubation was performed with GST-C/Nestin fusion protein (Fig. 3E).

\section{Differentiation of RC2.E10 cells into an astrocyte-like phenotype by cAMP}

For differentiation experiments, cells were incubated at $39^{\circ} \mathrm{C}$ in defined medium containing bFGF. The morphology of RC2.E10 cells maintained under these conditions was not appreciably different from those maintained at $33^{\circ} \mathrm{C}$ in DMEM and $10 \% \mathrm{FBS}$. To explore the possibility that activation of the cAMP signaling pathway induces differentiative effects, we treated RC2.E10 cells with $1 \mathrm{~mm} 8 \mathrm{Br}-\mathrm{cAMP}$. Under these conditions, remarkable changes in cell morphology were observed. Cell bodies became comparatively small and spherical, and cells started to put out processes. These changes were initially apparent within 6-8 hr from the onset of treatment and developed over 12-16 hr (Fig. 4). A similar response was observed when forskolin $(10 \mu \mathrm{M})$, a direct activator of adenylate cyclase, was used (results not shown). In contrast, no morphological changes were observed when similar experiments were performed using a different cell line, RH1.C4 (Schwartz and Vallejo, 1998), established from developing rat hippocampus (results not shown). Changes in morphology induced by $8 \mathrm{Br}-\mathrm{cAMP}$ were also observed in cells growing at $33^{\circ} \mathrm{C}$. However, under these conditions, the observed changes were transient, and cells reverted to an undifferentiated morphology within $24-48 \mathrm{hr}$, thus indicating that stable differentiation cannot take place in the presence of the SV40T oncogene. In contrast, cells incubated at $39^{\circ} \mathrm{C}$ in defined medium retained the morphological changes induced by $8 \mathrm{Br}-\mathrm{cAMP}$ for at least 1 week after treatment, although survival was poor, and $>50 \%$ of cells died during that time.

Because RC2.E10 cells exhibit phenotypic features of neural precursors (bFGF-dependent proliferation, expression of nestin, 

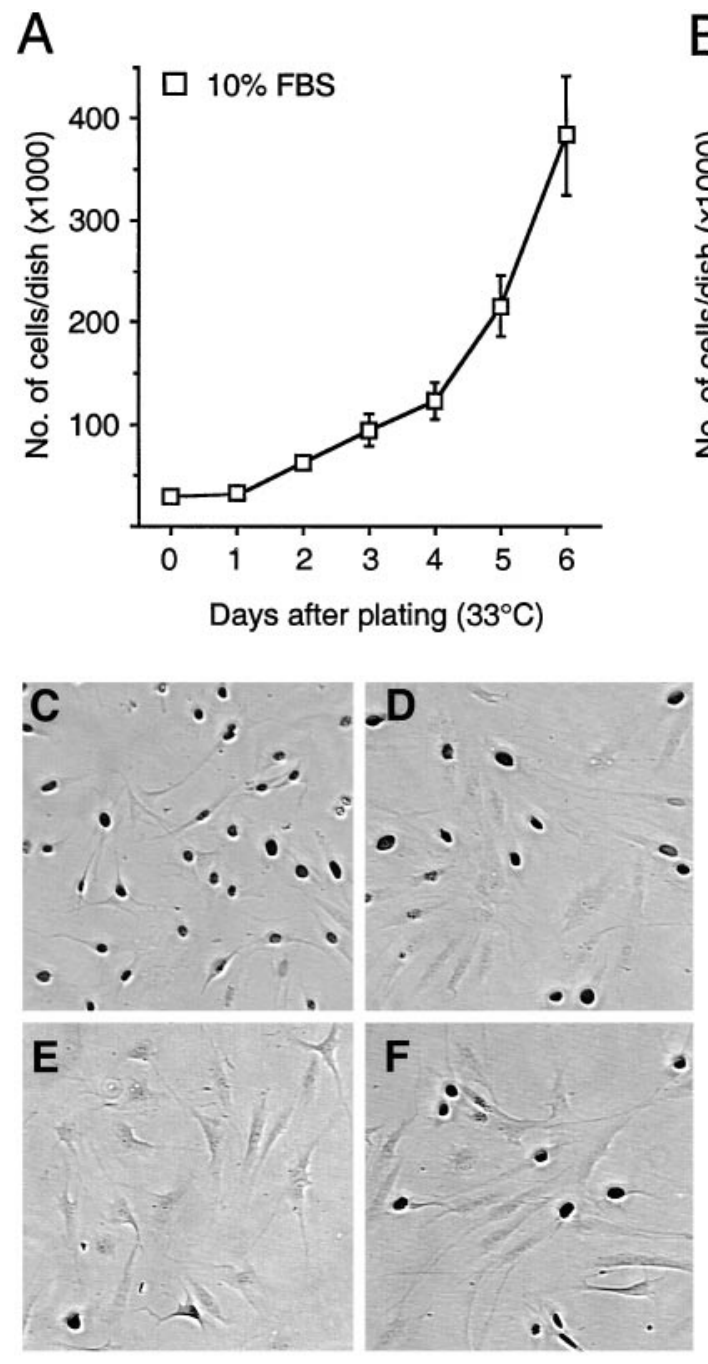
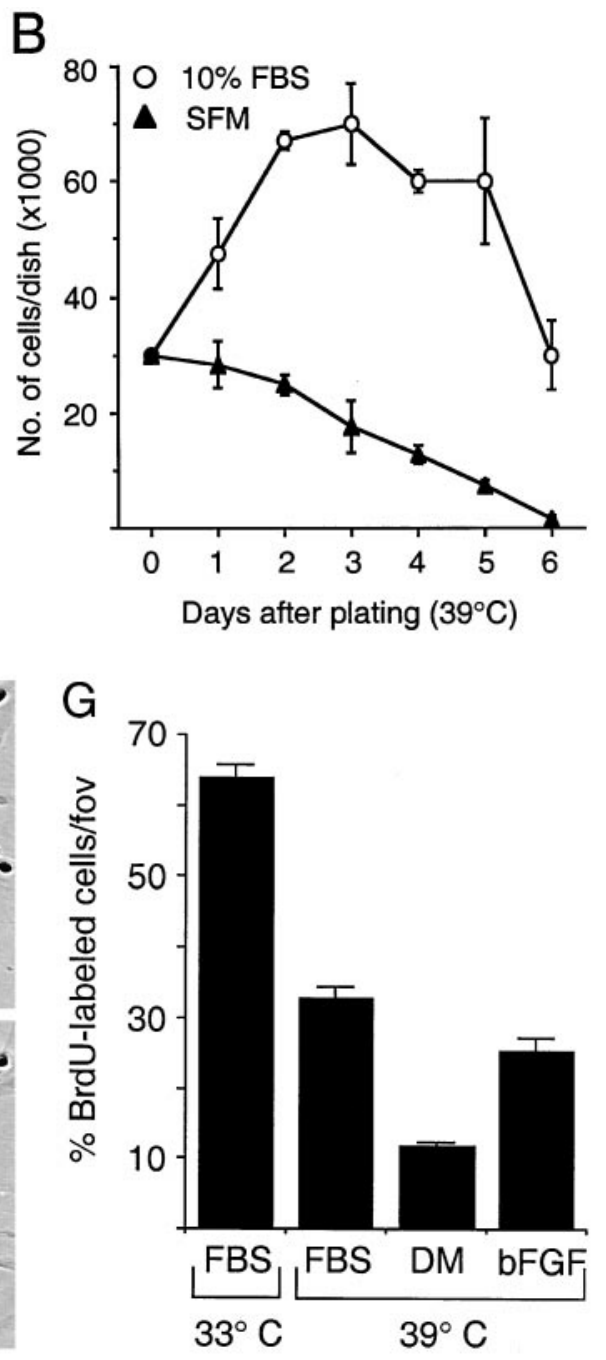

Figure 2. Growth curves and proliferation rates of RC2.E10 cells incubated under different culture conditions. $A, B$, Growth curves of RC2.E10 cells incubated at $33^{\circ} \mathrm{C}$ in DMEM and $10 \% \mathrm{FBS}(A)$ or at $39^{\circ} \mathrm{C}$ in either DMEM and $10 \%$ FBS or serum-free medium $(S F M)(B)$. Initial plating density was $3 \times 10^{4}$ cells per dish $(60 \mathrm{~mm}$ cell culture dishes were used). Values represent mean \pm SEM of six $(A)$ or four $(B)$ independent experiments. Some error bars are too small to be visible. $C-F$, Phasecontrast micrographs of RC2.E10 cells treated overnight with $10 \mu \mathrm{M} \mathrm{BrdU}$ and processed immunocytochemically with a monoclonal anti-BrdU antibody to determine nuclear incorporation. Culture conditions were as follows: $C, 33^{\circ} \mathrm{C}$ in DMEM and $10 \% \mathrm{FBS} ; D, 39^{\circ} \mathrm{C}$ in DMEM and $10 \%$ FBS; $E, 39^{\circ} \mathrm{C}$ in serum-free DMEM supplemented with $\mathrm{N} 1$ medium and sodium pyruvate (defined medium); and $F, 39^{\circ} \mathrm{C}$ in defined medium containing $20 \mathrm{ng} / \mathrm{ml}$ basic fibroblast growth factor. $G$, Quantification of the percentage of BrdU-positive cells per field of vision ( $f o v)$. Cells were visualized under light microscopy, and the number of immunocytochemically stained nuclei was counted. The total number of cells in the same field of vision was subsequently determined using phase-contrast microscopy. Values represent mean \pm SEM of data gathered from three experiments performed in duplicate. At least 10-12 fov per dish were examined. $D M$, Defined medium. and morphological differentiation), it was of interest to determine whether the differentiative response to $8 \mathrm{Br}$-cAMP represents a phenotypic transition involving the acquisition of neuronal or glial features. For this purpose, cells were cultured at $39^{\circ} \mathrm{C}$ in defined medium containing bFGF and were treated with 8Br-cAMP (1 $\mathrm{mm})$ for $16 \mathrm{hr}$ before evaluation. Phenotypic characterization of RC2.E10 cells was performed immunocytochemically, using monoclonal antibodies against well established markers such as the neuron-specific NCAM, calbindin, and MAP-2 (Matus et al., 1986; Ghosh and Greenberg, 1995; Johe et al., 1996); the astrocytespecific GFAP (Eng, 1985; Gross et al., 1996; Johe et al., 1996; Bonni et al., 1997; Koblar et al., 1998; Mi and Barres, 1999); S100 $\beta$, found predominantly in astrocytes (Hinkle et al., 1998; Mi and Barres, 1999); and the oligodendrocyte-specific galactocerebroside.

Undifferentiated, nestin-positive RC2.E10 cells did not stain for neuronal or glial markers (Fig. 4). After treatment with 8Br-cAMP, concomitant with the observed morphological changes, cells became strongly immunoreactive to GFAP, which was localized to the cell soma and processes (Fig. 4D). For quantification, 5-10 fields of vision per dish were examined in three different dishes from independent experiments, and the percentage of GFAP-positive cells relative to the total number of cells was determined to be $84 \pm 4.7$ (mean \pm SEM). RC2.E10 cells also stained immunopositively for $\mathrm{S} 100 \beta$ after treatment with 8Br-cAMP (Fig. $4 F$ ) (percentage of positive cells, $82 \pm 2.5$ ).
No staining for MAP-2 (Fig. 4H), NCAM, calbindin, or galactocerebroside (results not shown) was observed in differentiated cells, indicating the absence of neurons or oligodendrocytes. Western immunoblotting confirmed the increase in GFAP expression after treatment with $8 \mathrm{Br}$-cAMP (Fig. 4I). Immunocytochemistry and RT-PCR and Southern blot analysis revealed that differentiated RC2.E10 cells express reduced amounts of nestin (Fig. 5). Thus, these results are consistent with the notion that RC2.E10 cells acquire an astroglial phenotype after activation of the cAMP-dependent signaling pathway.

\section{Effects of cAMP stimulation on RC2.E10 cell proliferation}

The proliferative effects of growth factors, including bFGF, are associated with the phosphorylation-dependent activation of the mitogen-activated protein kinase (MAPK) signaling pathway. In many cell types, including astrocytes (Kurino et al., 1996), activation of MAPK is blocked by cAMP, resulting in decreased proliferation (for review, see Burgering and Bos, 1995). For this reason, we sought to determine whether the differentiative effects of $8 \mathrm{Br}$-cAMP on RC2.E10 cells may be related to a blockade of cell proliferation.

By determining the percentage of cells that incorporate BrdU, we found that RC2.E10 cell proliferation decreased significantly when cells cultured in the presence of bFGF were treated with 

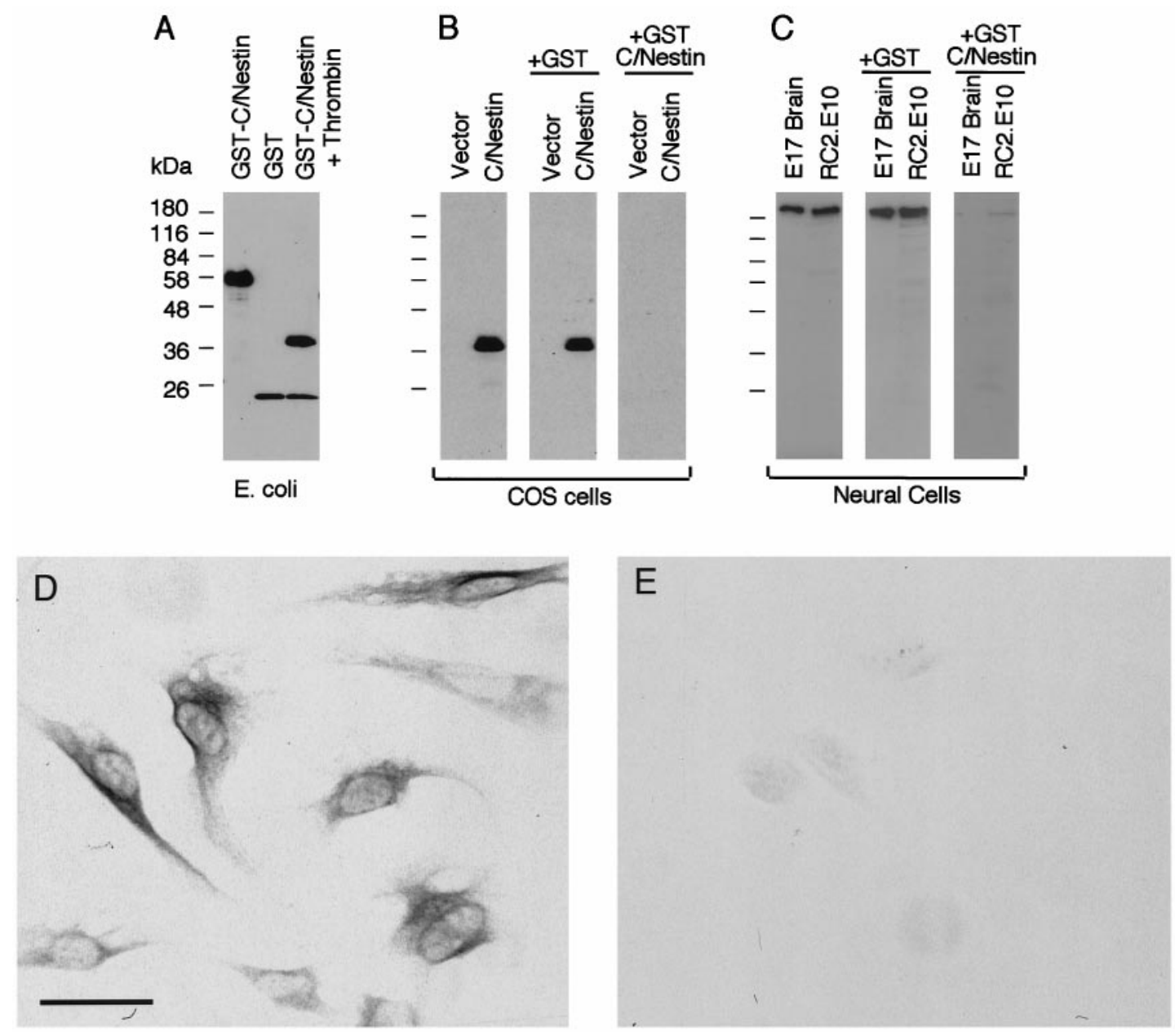

Figure 3. Characterization of nestin antiserum and expression of nestin in RC2.E10 cells. $A-C$, Western immunoblots of the following: $A$, GST-C/nestin fusion protein, either intact or cleaved with thrombin, and control GST, expressed in $E$. coli and purified on glutathione-Sepharose beads; $B$, lysates of COS cells transfected with pcDNAI (Vector) or with pcDNAI-C/Nestin (C/Nestin); and C, lysates of developing forebrain dissected from E17 rat embryos (E17 Brain) or of RC2.E10 cells. For cell lysates, $\sim 5 \mu \mathrm{g}$ of protein were loaded in each lane. When indicated, nestin antiserum (1:20,000 dilution) was preincubated with purified GST or GST-C/Nestin recombinant proteins $(60 \mathrm{ng} / \mathrm{ml} \mathrm{each).} D$, Immunocytochemical detection of nestin in RC2.E10 cells. E, RC2.E10 cells processed for nestin immunocytochemistry using antiserum preincubated with purified GST-C/Nestin fusion protein (60 $\mathrm{ng} / \mathrm{ml})$. Scale bar, $50 \mu \mathrm{m}$.

8Br-cAMP (Fig. 6). Inhibition of MAPK phosphorylation by 8Br-cAMP was monitored by Western immunoblotting, using a specific antibody (New England Biolabs) that specifically recognizes the phosphorylated Erk-1 and Erk-2 MAPK isoforms (results not shown). Treatment of RC2.E10 cells with PD98059, a specific inhibitor of MAPK phosphorylation (Alessi et al., 1995), resulted in a significant decrease in the number of cells proliferating in the presence of $\mathrm{bFGF}$, similar to that observed after treatment with 8Br-cAMP (Fig. 6). However, no morphological differentiation and no increase in GFAP expression, as assessed immunocytochemically, were observed in PD98059-treated cells, indicating that astrocyte differentiation is not simply a result of blocking cell proliferation.

\section{cAMP stimulation induces astroglial differentiation of primary cortical precursors}

Because of the clonal nature of RC2.E10 cells, it is formally possible that they may represent a specific nonabundant type of cortical precursor cell expanded in vitro after immortalization. If that were the case, their capacity to differentiate in response to activation of the cAMP-dependent pathway would not be repre- sentative of whether a large number of neural precursors present in the developing cortex have the competence to differentiate into astrocytes after stimulation of this signaling pathway. To address this question, we performed experiments in primary cultures of cortical precursors prepared from E17 rats.

Cortical cells maintained in defined medium in the presence of bFGF were uniformly immunopositive for nestin, indicating that they are neuroepithelial precursors (Fig. 7D). They exhibited no immunoreactivity for the lineage-specific markers GFAP (Fig. $7 A$ ), MAP-2, NCAM, and galactocerebroside (results not shown). Withdrawal of bFGF for $2 \mathrm{~d}$ did not cause appreciable cell death and resulted in the appearance of GFAP immunoreactivity in $5-10 \%$ of cells (mean \pm SEM, $7.4 \pm 2.2$ ). In contrast, when $8 \mathrm{Br}$-cAMP $(1 \mathrm{mM})$ or forskolin $(10 \mu \mathrm{M})$ was added to the medium immediately after bFGF withdrawal, the percentage of GFAP-positive cells rose to $72 \pm 4.7$ after 2 d. GFAP-positive cells exhibited morphological features typical of astrocytes, extending relatively short processes $(<20 \mu \mathrm{m}$ in most cells) and acquiring a stellate morphology (Fig. $7 B$ ). The increase in GFAP expression after $8 \mathrm{Br}$-cAMP treatment was confirmed by Western 


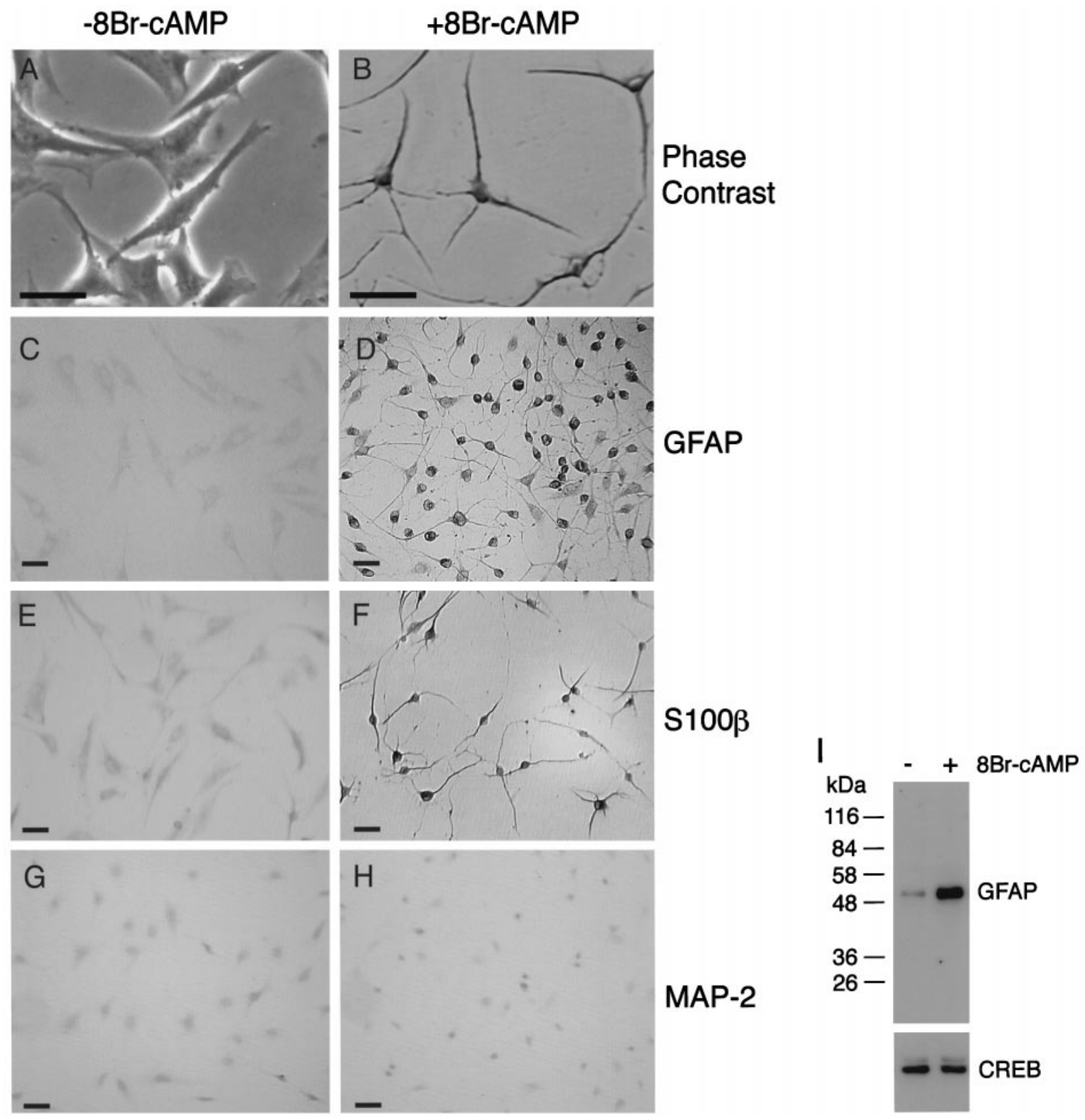

Figure 4. Astroglial differentiation of RC2.E10 cells induced by treatment with 8Br-cAMP. Cells were cultured at $39^{\circ} \mathrm{C}$ in defined medium in the presence of bFGF $(20 \mathrm{ng} / \mathrm{ml})$ and were left untreated $(A, C, E, G)$ or treated with $8 \mathrm{Br}$-cAMP $(1 \mathrm{~mm})$ overnight $(B, D, F, H)$. $A, B$, Phase-contrast micrographs taken at high magnification. At lower magnification, immunostainings for GFAP $(C, D), \mathrm{S} 100 \beta(E, F)$, or MAP-2 $(G, H)$ are shown. Scale bar, $50 \mu \mathrm{m}$. $I$, Western immunoblot showing increase in GFAP induced by $8 \mathrm{Br}$-cAMP. Lysates were prepared from cells growing at $39^{\circ} \mathrm{C}$ in defined medium containing bFGF $(20 \mathrm{ng} / \mathrm{ml})$ and left untreated $(-)$ or from cells cultured in the same conditions but treated with $8 \mathrm{Br}-\mathrm{cAMP}(1 \mathrm{mM})$ overnight $(+)$. CREB immunoreactivity was used as a control to ensure that similar amounts of protein were loaded in each lane. Approximately $5 \mu \mathrm{g}$ of protein were loaded in each lane.

immunoblotting (Fig. 7G). When cells were left in culture for $5 \mathrm{~d}$ after the addition of $8 \mathrm{Br}-\mathrm{cAMP}$, they exhibited intense GFAP immunostaining, and the processes displayed a more elaborate morphology and greater length $(50-100 \mu \mathrm{m})$ than those cultured for $2 \mathrm{~d}$ (Fig. $7 C$ ). Cells treated with 8Br-cAMP did not express MAP-2, NCAM, or galactocerebroside (results not shown), suggesting that activation of the cAMP-dependent pathway in neural precursors does not promote neuronal or oligodendroglial differentiation.

Inhibition of nestin expression has been associated with terminal differentiation of neural cells. However, it has been reported that at least some astrocytes can express both nestin and GFAP (Johe et al., 1996; Bonni et al., 1997; Rajan and McKay, 1998). To investigate whether exposure to cAMP has any effect on nestin expression in primary cortical precursors, we performed immunocytochemistry on cells treated with $8 \mathrm{Br}-\mathrm{cAMP}$ for 2 or $5 \mathrm{~d}$. Nestin immunoreactivity was less intense $2 \mathrm{~d}$ after treatment, relative to control untreated cells, and decreased even further $5 \mathrm{~d}$ after treatment (Fig. $7 D-F$ ). Thus, expression of nestin was reduced in a time-dependent manner and, in general, cells that displayed a more elaborate, differentiated morphology were less immunoreactive for nestin (Fig. $7 F$ ). 

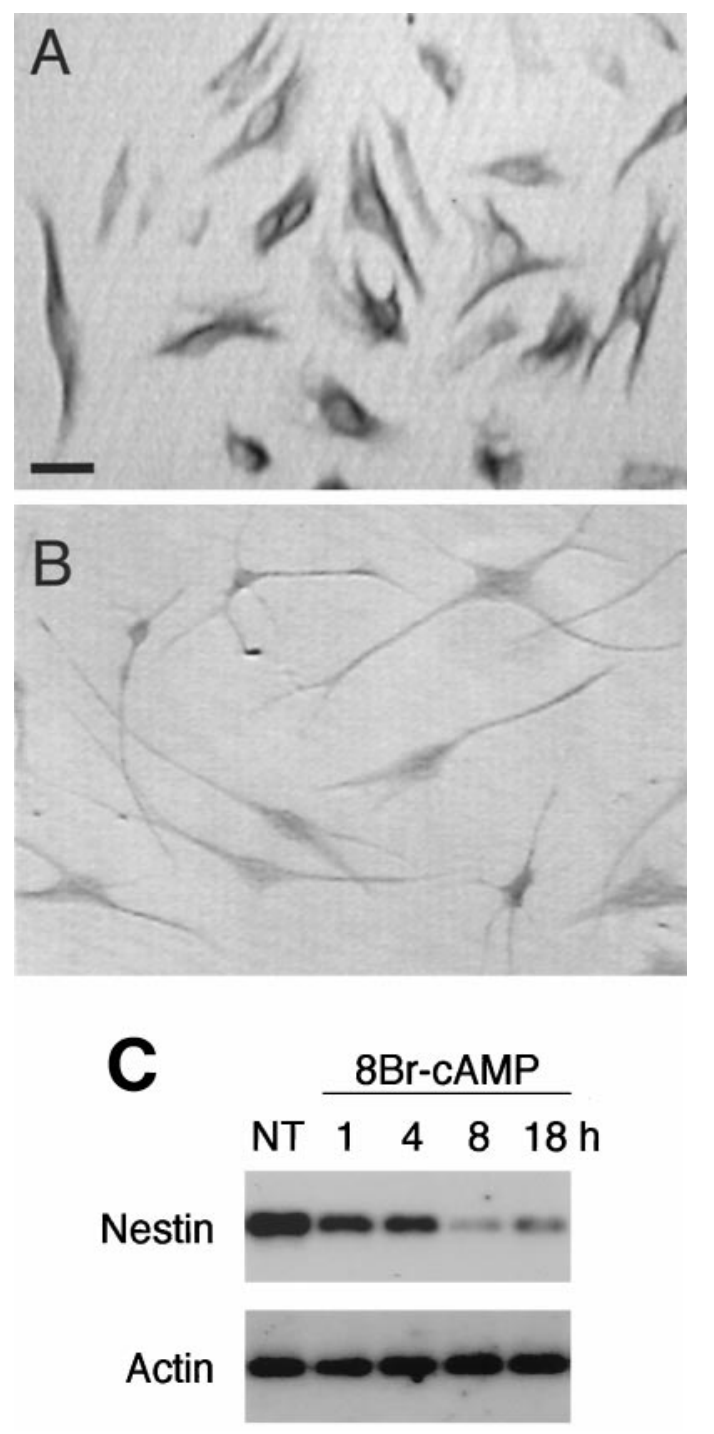

Figure 5. Decrease of nestin gene expression after treatment of RC2.E10 cells with 8Br-cAMP. $A, B$, Nestin immunostaining of RC2.E10 cells cultured at $39^{\circ} \mathrm{C}$ in defined medium in the presence of bFGF $(20 \mathrm{ng} / \mathrm{ml})$ before $(A)$ or after $(B)$ an overnight treatment with $1 \mathrm{~mm} 8 \mathrm{Br}$-cAMP. Scale bar, $50 \mu \mathrm{m}$. $C$, RT-PCR and Southern blot hybridization analysis of nestin transcripts from RC2.E10 cells that received either no treatment $(N T)$ or $8 \mathrm{Br}-\mathrm{cAMP}(1 \mathrm{mM})$ for the indicated times before harvesting.

\section{Cell proliferation and astrocyte differentiation}

Consistent with results obtained with RC2.E10 cells, treatment of primary cortical precursors growing in the presence of bFGF with $8 \mathrm{Br}-\mathrm{cAMP}$ resulted in the rapid and long-lasting inhibition of Erk-1 and Erk-2 phosphorylation (results not shown). We determined that, in the presence of bFGF, $>70 \%$ of primary cortical precursor cells incorporate BrdU after a $5 \mathrm{hr}$ labeling time (mean \pm SEM, $72 \pm 5.5$ ). To investigate whether activation of the cAMP signaling pathway has an effect on cellular proliferation of cortical precursors, we determined the relative number of cells that incorporate BrdU after exposure to $8 \mathrm{Br}-\mathrm{cAMP}$. For this purpose, cells were treated after withdrawal of bFGF with $8 \mathrm{Br}-$ cAMP for $2 \mathrm{~d}$ and received a pulse of BrdU $5 \mathrm{hr}$ before harvesting. As shown in Figure $8 A$, exposure of primary cultured cortical cells to $8 \mathrm{Br}$-cAMP did not increase BrdU incorporation relative to control cells. Similar results were obtained when BrdU labeling

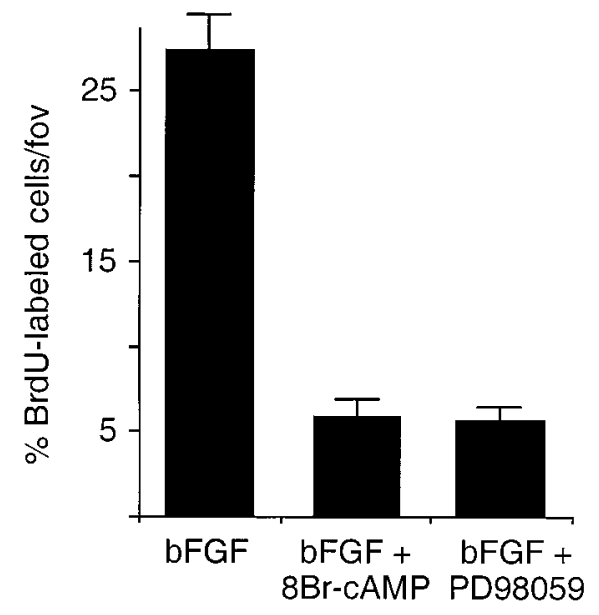

Figure 6. Inhibition of RC2.E10 cell proliferation by $8 \mathrm{Br}-\mathrm{cAMP}$. Cells were cultured at $39^{\circ} \mathrm{C}$ in the presence of bFGF $(20 \mathrm{ng} / \mathrm{ml})$. Either 8Br-cAMP (1 mM) or the inhibitor PD98059 $(20 \mu \mathrm{M})$ was added concomitantly with BrdU $(10 \mu \mathrm{M}) 16 \mathrm{hr}$ before harvesting. Quantification of the percentage of BrdU-positive cells per field of vision ( fov) is represented. Values are mean \pm SEM of data gathered from three experiments performed in duplicate. At least 10-12 fov per dish were examined.

was performed overnight (results not shown). Thus, cAMP stimulation does not induce proliferation of cortical precursors.

In addition, we performed dual-antigen immunocytochemistry with BrdU and GFAP antibodies to determine whether cAMP stimulation may result in the stimulation of proliferation of a small subset of GFAP-positive astrocyte precursors. We found that the vast majority of cells that stained for BrdU did not stain for GFAP, and the vast majority of astrocytes did not stain for BrdU (Fig. 8B). The number of cells that stained for both BrdU and GFAP accounted for $<1 \%$. Taken together, these experiments suggest that $8 \mathrm{Br}-\mathrm{cAMP}$ is not acting on a small proportion of cortical precursors or specifically stimulating the proliferation of cells of the astrocyte lineage. Thus, activation of the cAMPdependent signaling pathway appears to induce differentiation of cortical precursors along the astrocyte lineage.

\section{DISCUSSION}

\section{cAMP stimulation provides an additional route to astrocyte differentiation}

Two major signal transduction pathways have been implicated so far in the generation of astrocytes in the CNS. One is the JAK-STAT signaling pathway that activates GFAP gene expression in response to CNTF (Johe et al., 1996; Bonni et al., 1997; Koblar et al., 1998; Rajan and McKay, 1998). The other signaling pathway is activated by members of the bone morphogenetic proteins (Gross et al., 1996) and most likely involves activation of Smad proteins (Ebendal et al., 1998; Zhang et al., 1998). Our results suggest that the cAMP-dependent signaling pathway may represent an additional or alternative mechanism to promote astrocyte differentiation.

An increase in intracellular levels of cAMP activates different signaling pathways (Vossler et al., 1997; Kawasaki et al., 1998), the best known of which leads to activation of PKA and phosphorylation of CREB and CREB-related transcription factors (Montminy, 1997). The notion that CREB may participate in the observed astrocytic differentiation response is supported by our finding that treatment of RC2.E10 cells or primary cortical precursors with $8 \mathrm{Br}-\mathrm{cAMP}$ or forskolin results in the rapid but 


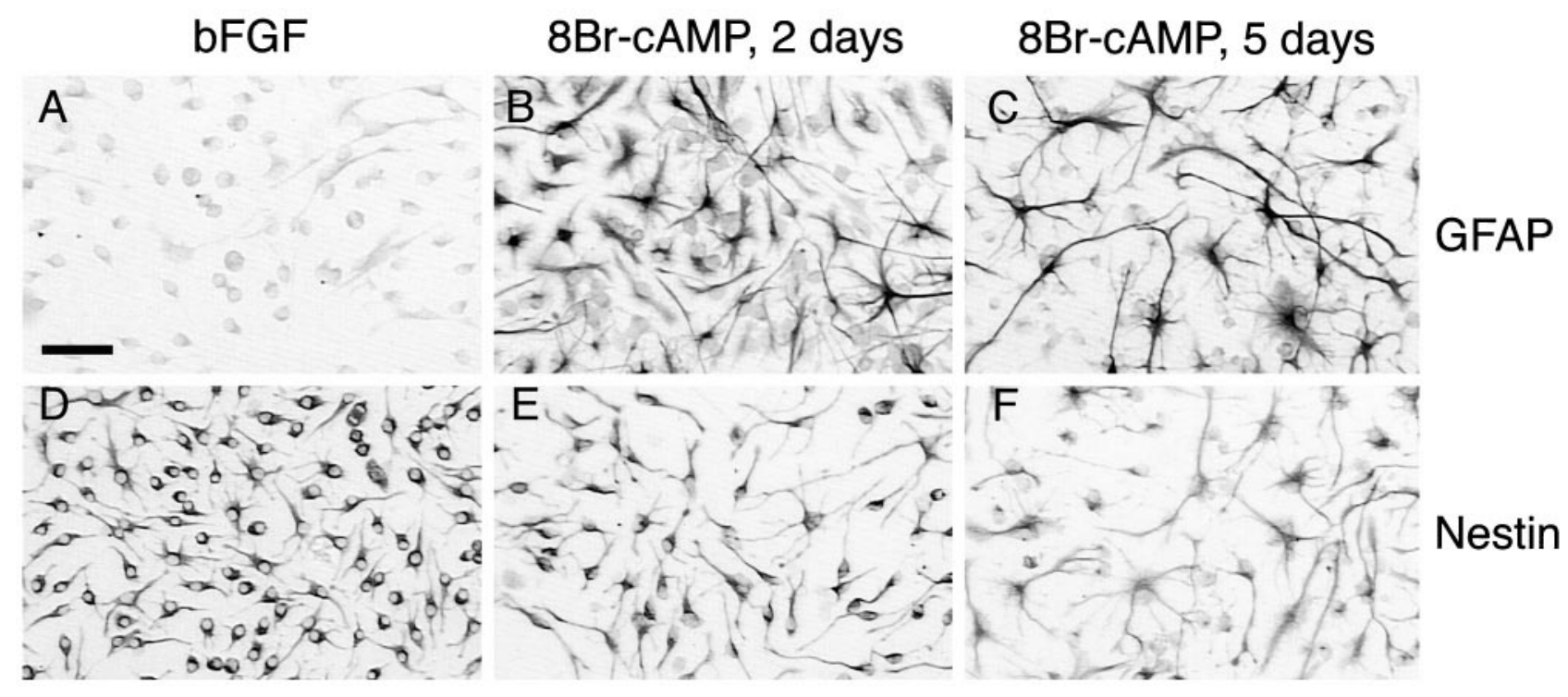

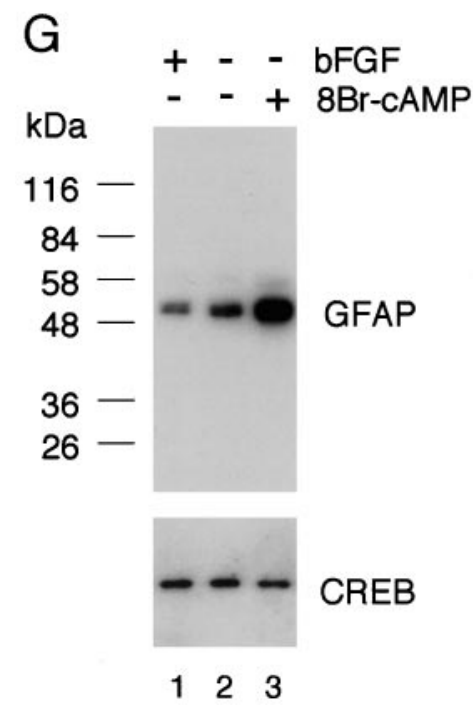

transient phosphorylation of CREB, being evident within 5 min and lasting for $\sim 30 \mathrm{~min}$ (M. F. McManus, L.-C. Chen, and I. Vallejo, unpublished observations). However, treatment of RC2.E10 cells or primary cortical precursors with serum, bFGF, or glutamate, agents that did not induce astrocyte differentiation, resulted in rapid but long-lasting ( $>4 \mathrm{hr}$ ) phosphorylation of CREB; therefore CREB phosphorylation per se does not appear to be sufficient to promote astrocyte differentiation.

An association between cAMP production and the development or maintenance of a neuronal or glial phenotype has been observed both in the peripheral and central nervous systems. Thus, elevated intracellular levels of cAMP appear to be important for Schwann cell differentiation (Stemple and Anderson, 1992) and for survival of spinal motor neurons (Hanson et al., 1998 ) or astrocyte precursor cells from the optic nerve (Mi and Barres, 1999). In addition, cAMP has been previously shown to stimulate GFAP gene expression (Kaneko et al., 1994; Segovia et al., 1994) and to alter the morphology of astrocytes (Shain et al., 1987; Goldman and Abramson, 1990; Imamura and Ozawa, 1998). Our results now suggest that cAMP acts in undifferentiated neural precursors to induce a phenotypic transition that results in the generation of astrocytes.
Figure 7. Astroglial differentiation of primary cortical precursor cells induced by cAMP stimulation. Cells were cultured in defined medium in the presence of bFGF $(20 \mathrm{ng} / \mathrm{ml})$ and processed for immunostaining of GFAP $(A)$ or nestin $(D)$. After withdrawal of bFGF, cells were treated with $8 \mathrm{Br}$-cAMP $(1 \mathrm{mM})$ for either $2 \mathrm{~d}(B, E)$ or $5 \mathrm{~d}(C, F)$, after which they were fixed and processed for immunocytochemistry for GFAP $(B, C)$ or nestin $(E, F)$. Note that in $F$, cells with more elaborate morphology exhibit less intense nestin immunostaining. Scale bar, $50 \mu \mathrm{m}$. $G$, Western immunoblot showing increase in GFAP induced by $8 \mathrm{Br}$-cAMP. Lysates were prepared from cells growing in defined medium containing bFGF (20 ng/ml) (lane 1) or from cells that had been withdrawn from bFGF and left untreated for $2 \mathrm{~d}$ (lane 2) or treated with 8Br-cAMP (1 mM) for $2 \mathrm{~d}$ (lane 3). CREB immunoreactivity was used as a control to ensure that similar amounts of protein were loaded in each lane. Approximately $5 \mu \mathrm{g}$ of protein were loaded in each lane.

Multipotential neural precursors can undergo phenotypic transitions when exposed to single factors (Johe et al., 1996). Thus, it follows that the activation of specific intracellular signaling pathways appear to be sufficient to trigger differentiation, possibly by implementing changes in the expression of specific sets of genes via activation of appropriate transcriptional mechanisms. That activation of the cAMP-dependent signaling pathway triggers astrocyte differentiation implies the possible existence of ligands in the developing CNS, such as monoamines and neuropeptides, that promote gliogenesis by acting on $\mathrm{G}$ protein-coupled receptors signaling via cAMP production. Receptors for the monoamine neurotransmitters serotonin, noradrenaline, and dopamine are expressed in neural precursors in the developing brain, and their ligands, present in axons that originate in the brainstem and midbrain, reach the developing cerebral cortex before the onset of gliogenesis. An increasing amount of data indicates that some of these monoamines have effects on cortical development, and thus they may have trophic functions before acquiring their known role as neurotransmitters (Lauder, 1993; Lavdas et al., 1997; Levitt et al., 1997; Naqui et al., 1999). In concert with this notion, we found that monoamines induce the phosphorylation of CREB in primary cultures of E17 cortical precursor cells (L.-C. Chen 

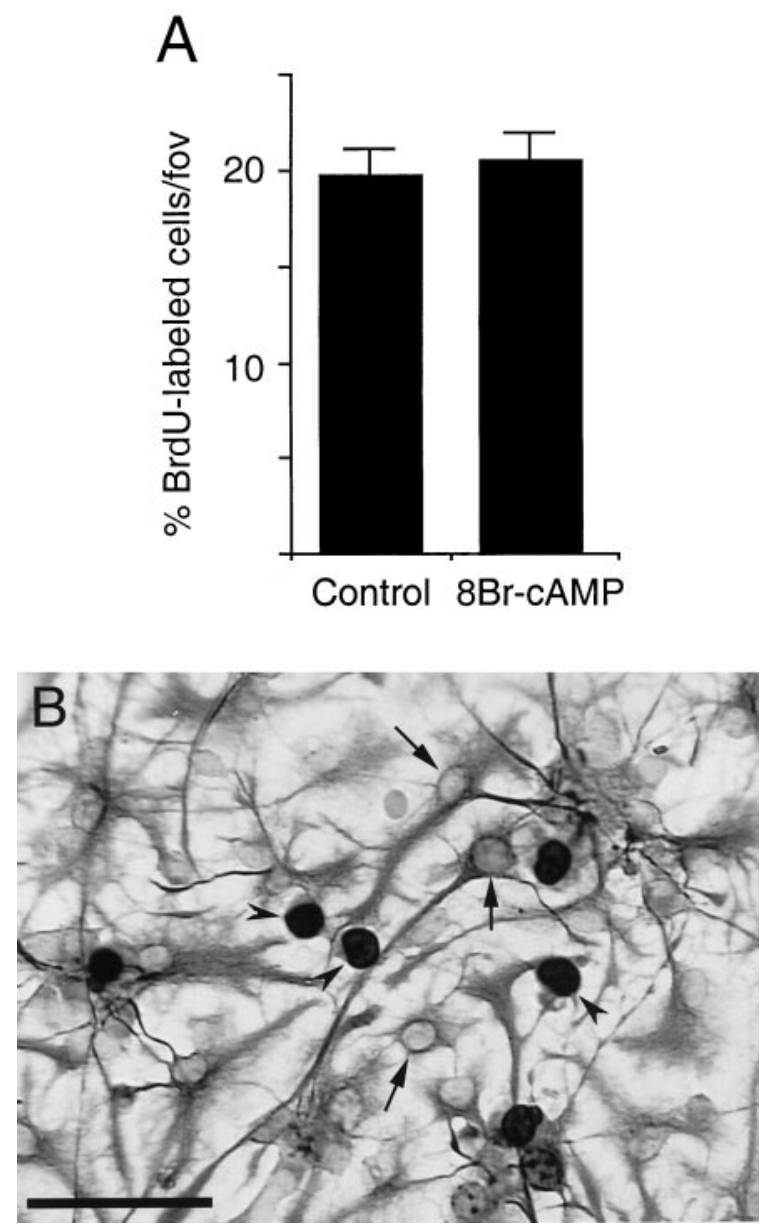

Figure 8. cAMP stimulation does not induce proliferation of astrocytes. $A$, Percentages of primary cortical cells that incorporate BrdU per field of vision (fov). Cells were grown in defined medium without treatment (Control) or in the presence 8Br-cAMP $(1 \mathrm{mM})$ for $2 \mathrm{~d}$. BrdU $(10 \mu \mathrm{M})$ was added $5 \mathrm{hr}$ before fixation and subsequent immunostaining with an anti-BrdU antibody. Quantification of BrdU-positive cells was performed as described in Materials and Methods and in the legend to Figure 2G. B, Dual-antigen BrdU-GFAP immunostaining of primary cortical cells treated for $2 \mathrm{~d}$ with $8 \mathrm{Br}$-cAMP $(1 \mathrm{mM})$, to which a pulse of $\mathrm{BrdU}(10 \mu \mathrm{M})$ was added for $5 \mathrm{hr}$ before harvesting. Note that BrdU staining is confined to cells that do not stain for GFAP. Representative examples of BrdUimmunostained nuclei and GFAP-positive cells are indicated by arrowheads and arrows, respectively. Scale bar, $25 \mu \mathrm{m}$.

and I. Vallejo, unpublished observations). In addition, neuropeptides such as somatostatin, vasoactive intestinal peptide, substance $\mathrm{P}$, and enkephalins are present in small cortical interneurons before the onset of gliogenesis, and a role for some of them in neural development has been suggested (Cameron et al., 1998). Whether monoamines or neuroactive peptides act directly on undifferentiated cortical precursor cells during development to promote the differentiation of astrocytes merits further investigation.

\section{RC2.E10 cells as a model for cortical astrocyte differentiation}

RC2.E10 cells were derived from the embryonic cerebral cortex at a time during development (E16) at which this structure is rich in actively proliferating neural precursor cells (Altman and Bayer, 1991; Ghosh and Greenberg, 1995). Many SV40T-immortalized neural cells retain their capacity to differentiate once the immor- talizing oncogene has been inactivated (Frederiksen et al., 1988; Whittemore and White, 1993; Eaton et al., 1995; Rozental et al., 1995; Martínez-Serrano and Björklund, 1997; Qi et al., 1997). We show that, after degradation of the SV40T, RC2.E10 cells differentiate after activation of the cAMP-dependent signaling pathway to acquire an astrocyte-like phenotype and thus recapitulate phenotypic properties of neural precursor cells that can differentiate in vitro in response to specific stimuli. We did observe, however, one important difference between differentiated RC2.E10 cells and astrocytes generated from primary cortical precursors. In contrast to primary cells used in this study, RC2.E10 cell survival after treatment with $8 \mathrm{Br}$-cAMP for several days was poor. This difference may simply be attributable to their clonal origin, although phenotypic alterations resulting from the immortalization process cannot be ruled out.

One key feature of RC2.E10 cells is that they retain phenotypic features of neural precursors. These include (1) expression of nestin, (2) requirement of bFGF for proliferation, (3) stimulusdependent morphological differentiation and stimulation of GFAP expression, and (4) decrease in nestin expression concomitant with the acquisition of a differentiated phenotype. In addition, neuroepithelial cells present in the developing CNS maintain the expression of region-specific homeodomain transcription factors likely to control cell autonomous mechanisms of differentiation even after dispersion and immortalization in vitro (Nakagawa et al., 1996). In agreement with this notion, we found that RC2.E10 cells express the homeodomain genes Otx-1, Otx-2, Dlx-1, and Dlx-2 (data not shown), which encode transcription factors that participate in forebrain development (Acampora et al., 1995, 1996; Anderson et al., 1997). Of note, RC2.E10 cells do not undergo spontaneous differentiation when the immortalizing oncogene is inactivated. Instead, activation of the intracellular cAMP signal transduction pathway is necessary to trigger the differentiative response. This observation further suggests that in the developing mammalian cortex a subset of progenitor cells may respond to ligands that signal via cAMP to initiate astrocyte differentiation.

\section{Precursor cell proliferation and astrocyte differentiation}

An inhibitory effect of cAMP on activation of MAPK has been described in various cell types, including astrocytes (Burgering and Bos, 1995; Kurino et al., 1996). This inhibitory effect appears to be secondary to PKA-dependent phosphorylation of Raf-1, thus preventing the activation of MAPK (Burgering and Bos, 1995; Kurino et al., 1996). We observed a decrease in the levels of phosphorylated MAPK in neural precursors that differentiate into astrocytes in response to cAMP stimulation. However, it is unlikely that inhibition of MAPK phosphorylation is sufficient for initiating the differentiation response, because we did not observe differentiative changes in cells that were treated with PD98059. Therefore, cAMP stimulation may act as a gating mechanism (Iyengar, 1996) to synchronize the exit from the cell cycle, by inhibiting MAPK-dependent proliferation, with the onset of the differentiation response. Our double-antigen immunocytochemical studies on primary cortical cells support this notion, because we found that the vast majority of differentiated astrocytes were postmitotic and did not incorporate BrdU.

Our study supports the notion that the effect of cAMP stimulation is instructive on the promotion of astrocyte differentiation from undifferentiated cortical precursors, rather than selective on survival of astrocytes. This conclusion is supported by the follow- 
ing observations: (1) practically all primary cells maintained in the presence of bFGF stained strongly and uniformly for nestin, but not for glial or neuronal markers, and incorporated BrdU actively, indicating that they are proliferating neuroepithelial precursors; (2) withdrawal of bFGF did not result in cell death; (3) after bFGF withdrawal and cAMP stimulation, $70-80 \%$ of cells turned GFAP-positive, indicating the occurrence of an instructive phenotypic transition; and (4) BrdU incorporation after bFGF withdrawal did not increase in response to of $8 \mathrm{Br}$-cAMP. The latter is important because if cAMP stimulation acted on the selective survival of a small number of preexisting astrocytes, rather than on differentiation of precursors, the dramatic increase observed in the number of GFAP-positive cells would imply the occurrence of a significant proliferative activity of astrocytes after withdrawal of bFGF and treatment with 8Br-cAMP. Our BrdU incorporation data indicate that this is not the case, because withdrawal of bFGF resulted in decreased proliferation, and 8Br-cAMP did not increase BrdU incorporation relative to untreated cells. In addition, dual antigen immunocytochemical studies clearly indicated that GFAP-expressing cells do not proliferate.

Our findings add to the complexity of mechanisms that are probably required to integrate a wide variety of signals acting coordinately in a time- and space-dependent manner to generate astrocytes in the developing brain. Thus, identification of ligands that promote gliogenesis by increasing intracellular levels of cAMP and elucidation of the intracellular events that follow cAMP stimulation in neural precursors should increase our understanding of the mechanisms that lead to the restriction of the developmental fate of developing cells along an astrocyte phenotype.

\section{REFERENCES}

Acampora D, Mazan S, Lallemand Y, Avantaggiato V, Maury M, Simeone A, Brulet P (1995) Forebrain and midbrain regions are deleted in Otx2 ${ }^{-1-}$ mutants due to a defective anterior neuroectoderm specification during gastrulation. Development 121:3279-3290.

Acampora D, Mazan S, Avantaggiato V, Barone P, Tuorto F, Lallemand Y, Brulet P, Simeone A (1996) Epilepsy and brain abnormalities in mice lacking the Otx1 gene. Nat Genet 14:218-222.

Alessi DR, Cuenda A, Cohen P, Dudley DT, Saltiel AR (1995) PD098059 is a specific inhibitor of the activation of mitogen-activated protein kinase in vitro and in vivo. J Biol Chem 270:27489-27494.

Almazan G, McKay R (1992) An oligodendrocyte precursor cell line from rat optic nerve. Brain Res 579:234-245.

Altman J, Bayer R (1991) Neocortical development. New York: Raven. Anderson SA, Qiu M, Bulfone A, Eisenstat DD, Meneses J, Pedersen R, Rubenstein JLR (1997) Mutations of the homeobox genes Dlx-1 and Dlx-2 disrupt the striatal subventricular zone and differentiation of late born striatal neurons. Neuron 19:27-37.

Barres BA, Lazar MA, Raff MC (1994) A novel role for thyroid hormone, glucocorticoids and retinoic acid in timing oligodendrocyte development. Development 120:1097-1108.

Bonni A, Sun Y, Nadal-Vicens M, Bhatt A, Frank DA, Rozovsky I, Stahl N, Yancopoulos GD, Greenberg ME (1997) Regulation of gliogenesis in the central nervous system by the JAK-STAT signaling pathway. Science 278:477-483.

Bottenstein JE, Sato GH (1979) Growth of rat neuroblastoma cell line in serum-free supplemented medium. Proc Natl Acad Sci USA 76:514-517.

Brüstle O, Spiro AC, Karram K, Choudhary K, Okabe S, McKay RDG (1997) In vitro-generated neural precursors participate in mammalian brain development. Proc Natl Acad Sci USA 94:14809-14814.

Burgering BMT, Bos JL (1995) Regulation of Ras-mediated signaling: more than one way to skin a cat. Trends Biochem Sci 20:18-22.

Cameron HA, Hazel TG, McKay RD (1998) Regulation of neurogenesis by growth factors and neurotransmitters. J Neurobiol 36:287-306.

Cato ACB, Miksicek R, Schütz G, Arnemann J, Beato M (1986) The hormone regulatory element of mouse mammary tumor virus mediates progesterone induction. EMBO J 5:2237-2240.

Cavanagh JF, Mione MC, Pappas IS, Parnavelas JG (1997) Basic fibroblast growth factor prolongs the proliferation of rat cortical progenitor cells in vitro without altering their cell cycle parameters. Cereb Cortex 7:293-302.

Eaton MJ, Staley JK, Globus MYT, Whittemore SR (1995) Developmental regulation of early serotonergic neuronal differentiation: the role of brain-derived neurotrophic factor and membrane depolarization. Dev Biol 170:169-182.

Ebendal T, Bengtsson H, Soderstrom S (1998) Bone morphogenetic proteins and their receptors: potential functions in the brain. J Neurosci Res 51:139-146.

Eng LF (1985) Glial fibrillary acidic protein (GFAP): the major protein of glial intermediate filaments in differentiated astrocytes. J Neuroimmunol 8:203-214.

Fanning E (1992) Structure and function of simian virus 40 large tumor antigen. Annu Rev Biochem 61:55-85.

Finkbeiner S, Tavazoie SF, Maloratsky A, Jacobs KM, Harris KM, Greenberg ME (1997) CREB: a major mediator of neuronal neurotrophin responses. Neuron 19:1031-1047.

Frederiksen K, Jat PS, Valtz N, Levy D, McKay R (1988) Immortalization of precursor cells from the mammalian CNS. Neuron 1:439-448.

Gage FH, Ray J, Fisher L (1995) Isolation, characterization, and use of stem cells from the CNS. Annu Rev Neurosci 18:159-192.

Ghosh A, Greenberg ME (1995) Distinct roles for bFGF and NT-3 in the regulation of cortical neurogenesis. Neuron 15:89-103.

Goldman JE, Abramson B (1990) Cyclic AMP-induced shape changes in astrocytes are accompanied by rapid depolymerization of actin. Brain Res 528:189-196.

Gross RE, Mehler MF, Mabie PC, Zang Z, Santschi L, Kessler JA (1996) Bone morphogenetic proteins promote astroglial lineage commitment by mammalian subventricular zone progenitor cells. Neuron 17:595-606.

Guan K, Dixon JE (1991) Eukaryotic proteins expressed in E. coli: an improved thrombin cleavage and purification procedure of fusion proteins with glutathione $S$-transferase. Anal Biochem 192:262-267.

Halliday AL, Cepko CL (1992) Generation and migration of cells in the developing striatum. Neuron 9:15-26.

Hanson MG, Shen S, Wiemelt AP, McMorris FA, Barres B (1998) Cyclic AMP elevation is sufficient to promote the survival of spinal motor neurons in vitro. J Neurosci 18:7361-7371.

Hinkle DA, Harney JP, Cai A, Hilt DC, Yarowsky PJ, Wise PM (1998) Basic fibroblast growth factor- 2 and interleukin- $1 \beta$ regulate $\mathrm{S} 100 \beta$ expression in cultured astrocytes. Neuroscience 82:33-41.

Imamura M, Ozawa E (1998) Differential expression of dystrophin isoforms and utrophin during dibutyryl-cAMP-induced morphological differentiation of rat brain astrocytes. Proc Natl Acad Sci USA 95:6139-6144.

Iyengar R (1996) Gating by cyclic AMP: expanded role for an old signaling pathway. Science 271:461-463.

Jat PS, Sharp PA (1989) Cell lines established by a temperature-sensitive simian virus 40 large-T-antigen gene are growth restricted at the nonpermissive temperature. Mol Cell Biol 9:1672-1681.

Johe KK, Hazel TG, Muller T, Dugich-Djordjevic MM, McKay RDG (1996) Single factors direct the differentiation of stem cells from the fetal and adult central nervous system. Genes Dev 10:3129-3140.

Kaneko R, Hagiwara N, Leader K, Sueoka N (1994) Glial-specific cAMP response of the glial fibrillary acidic protein gene in the TR4 cell lines. Proc Natl Acad Sci USA 91:4529-4533.

Kawasaki H, Springett GM, Mochizuki N, Toki S, Nakaya M, Matsuda M, Housman DE, Graybiel AM (1998) A family of cAMP-binding proteins that directly activate Rap1. Science 282:2275-2279.

Koblar SA, Turnley AM, Classon BJ, Reid KL, Ware CB, Cheema SS, Murphy M, Bartlett PF (1998) Neural precursor differentiation into astrocytes requires signaling through the leukemia inhibitory factor receptor. Proc Natl Acad Sci USA 95:3178-3181.

Kurino M, Fukunaga K, Ushio Y, Miyamoto E (1996) Cyclic AMP inhibits activation of mitogen-activated protein kinase and cell proliferation in response to growth factors in cultures rat cortical astrocytes. J Neurochem 67:2246-2255.

Lauder JM (1993) Neurotransmitters as growth regulatory signals: role of receptors and second messengers. Trends Neurosci 16:233-240.

Lavdas AA, Blue ME, Lincoln J, Parnavelas JG (1997) Serotonin pro- 
motes the differentiation of glutamate neurons in organotypic slice cultures of the developing cerebral cortex. J Neurosci 17:7872-7880.

Lendahl U, Zimmerman LB, McKay RDG (1990) CNS stem cells express a new class of intermediate filament protein. Cell 60:585-595.

Levitt P, Harvey JA, Friedman E, Simansky K, Murphy EH (1997) New evidence for neurotransmitter influences on brain development. Trends Neurosci 20:269-274.

Liu FC, Graybiel AM (1996) Spatiotemporal dynamics of CREB phosphorylation: transient versus sustained phosphorylation in the developing striatum. Neuron 17:1133-1144.

Martínez-Serrano A, Björklund A (1997) Immortalized neural progenitor cells for CNS gene transfer and repair. Trends Neurosci 20:530-538.

Matus A, Bernhardt R, Bodmer R, Alaimos D (1986) Microtubuleassociated protein 2 and tubulin are differently distributed in the dendrites of the developing neurons. Neuroscience 17:371-389.

McKay R (1997) Stem cells in the central nervous system. Science 276:66-71.

Mi H, Barres BA (1999) Purification and characterization of astrocyte precursor cells in the developing rat optic nerve. J Neurosci 19:1049-1061.

Montminy M (1997) Transcriptional regulation by cAMP. Annu Rev Biochem 66:807-822.

Moore AN, Waxham MN, Dash PK (1996) Neuronal activity increases the phosphorylation of the transcription factor cAMP response element-binding protein (CREB) in rat hippocampus and cortex. J Biol Chem 271:14214-14220.

Moratalla R, Elibol B, Vallejo M, Graybiel AM (1996) Network-level changes in the expression of inducible Fos-Jun proteins in the striatum during chronic cocaine treatment and withdrawal. Neuron 17:147-156.

Murphy DD, Segal M (1997) Morphological plasticity of dendritic spines in central neurons is mediated by activation of cAMP response element binding protein. Proc Natl Acad Sci USA 94:1482-1487.

Nakagawa Y, Kaneko T, Ogura T, Suzuki T, Torii M, Kaibuchi K, Arai K, Nakamura S, Nakafuku M (1996) Roles of cell-autonomous mechanisms for differential expression of region-specific transcription factors in neuroepithelial cells. Development 122:2449-2464.

Naqui SZ, Harris BS, Thomaidou D, Parnavelas JG (1999) The noradrenergic system influences the fate of Cajal-Retzius cells in the developing cerebral cortex. Brain Res Dev Brain Res 113:75-82.

Pende M, Fisher TL, Simpson PB, Russell JT, Blenis J, Gallo V (1997) Neurotransmitter- and growth factor-induced cAMP response element binding protein phosphorylation in glial cell progenitors: role of calcium ions, protein kinase $\mathrm{C}$, and mitogen-activated protein kinase/ ribosomal S6 kinase pathway. J Neurosci 17:1291-1301.

Qi Y, Wang JKT, McMillan M, Chikaraishi DM (1997) Characterization of a CNS cell line, CAD, in which morphological differentiation is initiated by serum deprivation. J Neurosci 15:1217-1225.

Rajan P, McKay RDG (1998) Multiple routes to astrocytic differentiation in the CNS. J Neurosci 18:3620-3629.

Rao MS, Noble M, Mayer-Pröschel M (1988) A tripotential glial precursor cells is present in the developing spinal cord. Proc Natl Acad Sci USA 95:3996-4001.

Ray J, Peterson DA, Schinstine M, Gage FH (1993) Proliferation, dif- ferentiation, and long-term culture of primary hippocampal neurons. Proc Natl Acad Sci USA 90:3602-3606.

Reid CB, Liang I, Walsh C (1995) Systematic widespread clonal organization in cerebral cortex. Neuron 15:299-310.

Renfranz PJ, Cunningham MG, McKay RDG (1991) Region-specific differentiation of the hippocampal stem cell line HiB5 upon implantation into the developing mammalian brain. Cell 66:713-729.

Ron D, Habener JF (1992) CHOP, a novel developmentally regulated nuclear protein that dimerizes with transcription factors C/EBP and LAP and functions as a dominant-negative inhibitor of gene transcription. Genes Dev 6:439-453.

Rozental R, Mehler MF, Morales M, Andrade-Rozental AF, Kessler JA (1995) Differentiation of hippocampal progenitor cells in vitro: temporal expression of intercellular coupling and voltage- and ligand-gated responses. Dev Biol 167:350-362.

Schwartz PT, Vallejo M (1998) Differential regulation of basal and cyclic AMP-induced somatostatin gene transcription in neural cells by DNA control elements that bind homeodomain proteins. Mol Endocrinol 12:1280-1293.

Segal RA, Greenberg ME (1996) Intracellular signaling pathways activated by neurotrophic factors. Annu Rev Neurosci 19:463-489.

Segovia J, Lawless GM, Tillakaratne NJK, Brenner M, Tobin AJ (1994) Cyclic AMP decreases the expression of a neuronal marker $\left(\mathrm{GAD}_{67}\right)$ and increases the expression of an astroglial marker (GFAP) in C6 cells. J Neurochem 63:1218-1225.

Shain W, Forman DS, Madelian V, Turner JN (1987) Morphology of astroglial cells is controlled by beta-adrenergic receptors. J Cell Biol 105:2307-2314.

Snyder EY, Deitcher DL, Walsh C, Arnold-Aldea S, Hartwieg EA, Cepko CL (1992) Multipotent neural cell lines can engraft and participate in development of mouse cerebellum. Cell 68:33-51.

Stemple DL, Anderson DJ (1992) Isolation of a stem cell for neurons and glia from the mammalian neural crest. Cell 71:973-985.

Vicario-Abejón C, Cunningham MG, McKay RDG (1995a) Cerebellar precursors transplanted to the neonatal dentate gyrus express features characteristic of hippocampal neurons. J Neurosci 15:6351-6363.

Vicario-Abejón C, Johe KK, Hazel TG, Collazo D, McKay DG (1995b) Functions of basic fibroblast growth factor and neurotrophins in the differentiation of hippocampal neurons. Neuron 15:105-114.

Vossler MR, Yao H, York RD, Pan MG, Rim CS, Stork PJ (1997) cAMP activates MAP kinase and Elk-1 through a B-Raf- and Rap1dependent pathway. Cell 89:73-82.

Whittemore SR, White L (1993) Target regulation of neuronal differentiation in a temperature-sensitive cell line derived from medullary raphe. Brain Res 615:27-40.

Williams BP, Price J (1995) Evidence for multiple precursor cell types in the embryonic rat cerebral cortex. Neuron 14:1181-1188.

Xing J, Ginty DD, Greenberg ME (1996) Coupling of the RAS-MAPK pathway to gene activation by RSK2, a growth factor-regulated CREB kinase. Science 273:959-963.

Zhang D, Mehler MF, Song Q, Kessler JA (1998) Development of bone morphogenetic protein receptors in the nervous system and possible roles in regulating trkC expression. J Neurosci 18:3314-3326. 